Leonid Melnyk, Doctor of Economics, Professor, Head of the Department of Economics and Business Administration, Sumy State University (Sumy, Ukraine); Iryna Dehtyarova,

Candidate of Economic Sciences, Associate Professor, Associate Professor of the Department of Economics and Business Administration, Sumy State University (Sumy, Ukraine);

Denys Gorobchenko,

Candidate of Economic Sciences, Senior Lecturer of the Department of Economics and Business Administration, Sumy State University (Sumy, Ukraine);

Oleksandr Matsenko,

Candidate of Economic Sciences, Associate Professor, Associate Professor of the Department of Economics and Business Administration, Sumy State University (Sumy, Ukraine)

\title{
INNOVATIONS IN THE CONTEXT OF MODERN ECONOMIC TRANSFORMATION PROCESSES OF ENTERPRISE, REGION, COUNTRY: THE EU EXPERIENCE ${ }^{1}$
}

The article reveals the content of 'green' (sustainable) economy and the role of the Third Industrial Revolution (T.i.r.) and generated innovations in its formation. The article analyzes regularities of the T.i.r. origin and the prerequisites for its implementation. The main types of innovation transitions are considered when forming a new type of economy. The directions for transformation of economic systems at different levels are studied. The EU experience is analyzed.

Keywords: innovations, Third Industrial Revolution; renewable resources; 'green' (sustainable) economy; additive technologies; network.

DOI: $10.21272 / \mathrm{mmi} .2017 .4-23$

Formulation of the problem. It is extremely important to see the logics of the events taking place when analyzing the behavior of economic systems. It helps making reasonable decisions, and if possible avoiding mistakes that could lead to negative consequences in the future. This research is devoted to the analysis of cause-effect relationships and the role of innovations in the process of 'green' (sustainable) economy formation and implementation of the Third industrial revolution.

Unsolved problems. The Third industrial revolution (T.i.r.), which humanity is currently experiencing, was the reaction of human civilization to the inability to solve global environmental problems within the existing socio-economic formation. In scientific publications on this subject, mainly general questions of the T.i.r. are considered, that does not allow forming a systematic view of the cause-effect relationships and role of innovations that determine the T.i.r. phenomenon.

Analysis of recent research and publications. The main problems of modern transformation processes in the economy are considered in studies $[1 ; 11 ; 15 ; 25]$. The development of the main innovative solutions of the Third Industrial Revolution is presented in [28; 37; 38]. The influence of basic innovative technological innovations on the economies of different countries is presented in $[40 ; 43 ; 44 ; 46 ; 48]$.

Objective. The article analyzes regularities of innovations origin that determine the events of the T.i.r. and its influence on the formation of economic systems at different levels.

Research results.

1. The Legacy of the Second Industrial Revolution (S.i.r.). Apparently, people who lived at the turn of the $20^{\text {th }}$ and $21^{\text {st }}$ centuries could not even imagine that some hundred years ago their predecessors did

1 The article contains the results of research carried out in the framework of research № 0115U000684, № 0117U003260 
not enjoy electricity, communication (TV, radio, telephone), personal computer, cinema, modern modes of transport (car, airplane, metro) etc., so familiar to all of us at the end of the $20^{\text {th }}$ century. These and other important innovations of modern civilization were the result of the S.i.r. (Figure 1).

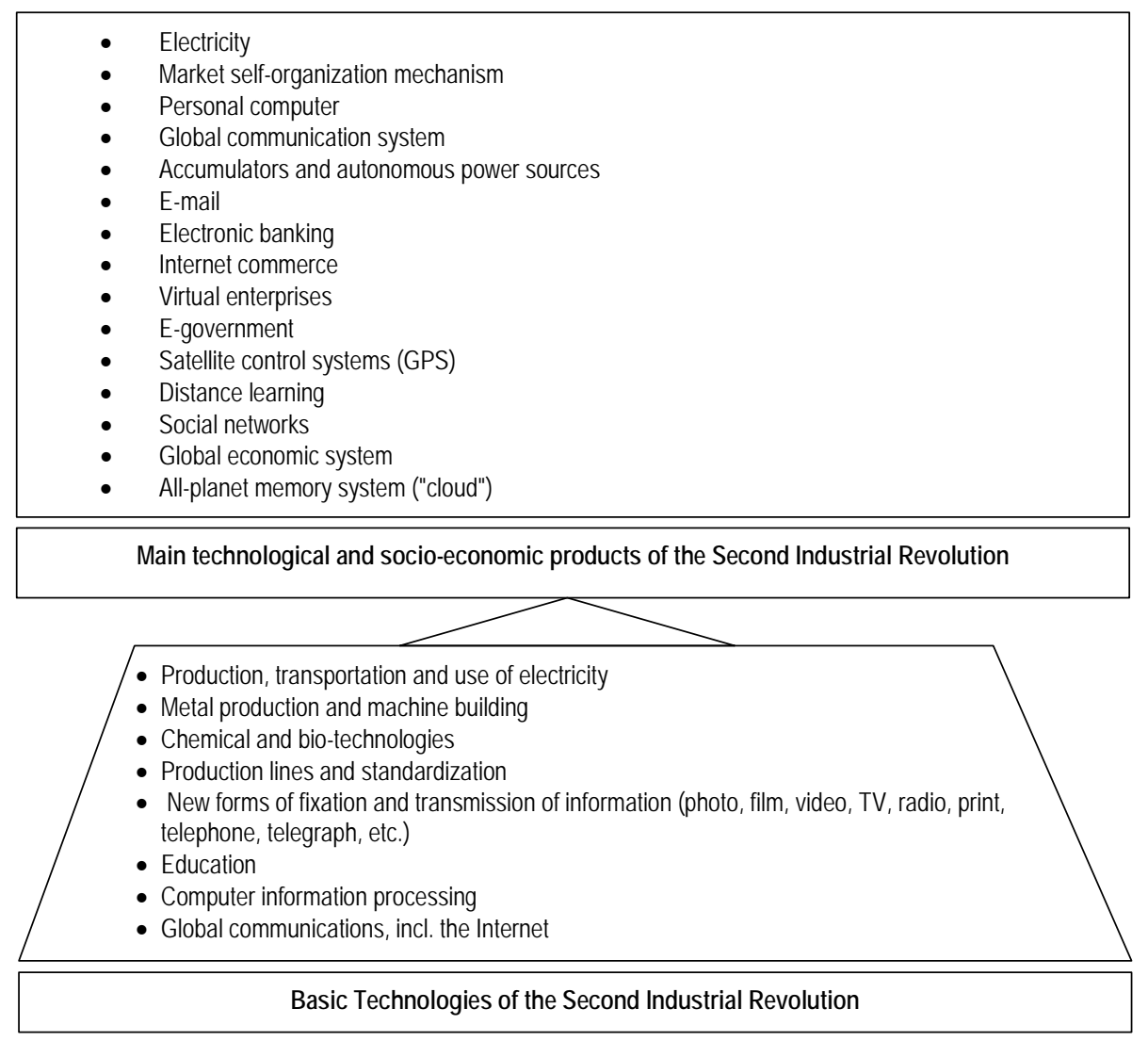

\section{Figure 1 - Technological and socio-economic heritage of The Second Industrial Revolution} (elaborated by the authors)

Meanwhile, it took only a dozen years to introduce quickly all these things into our life. Some 10-15 years ago we even had no idea about them, but it is already difficult to live our everyday life without mobile phones, digital communications, ATMs and, of course, the Internet. In fact, this is the legacy that the S.i.r. transmits to the T.i.r., aimed at solving the problems that could not be solved. Global ecological crisis is the most serious problem. Unprecedented resource-intensive industrial technologies brought by the S.i.r. caused this global ecological crisis.

One can discuss the conditional determinism of the beginning and end of any revolution. This means that, firstly, there is a certain cause that determines its occurrence, i.e. a complex of systemic contradictions which cannot be resolved in the conditions of the previous state of systems. Secondly, in order to solve the above contradictions, there is an objective set of system's parameters, to which the revolution must bring it along the development attractor, i.e. conditional trajectory of system's transformation. The phenomena that determine the cause of the revolution form necessary prerequisites 
for its realization and the socioeconomic system's development level forms sufficiency prerequisites.

The fundamental reason that grounds the emergence of the T.i.r. is the contradiction between the limited capacity of the natural resource potential of the planet and the excessive energy and material needs of mankind. Overproduction of energy from burning fossil fuels destroys the planet's energy system, and 'hard' technocratic methods of using the Earth's material resources undermine its ecosystems and the biosphere as a whole [36]. The T.i.r. is designed to ensure the transition to renewable energy and a significant (at times) increase in the efficiency of natural resources use.

2. Basic innovation trends of the Third Industrial Revolution (T.i.r.). The prevention of global ecological catastrophe and ensuring social (personal) development of a man are among the key tasks of the T.i.r. Actually, this is what the Declaration on Sustainable Development, adopted in 1992, says. In most Russian-language documents it is called 'ustoichivie razvitie' (ukr. 'stalyi rozvytok').

Existing natural and ecological realities, which ultimately impose restrictions on the development of productive forces and the corresponding parameters of the matter-energy metabolism of human civilization in the conditions of the Earth [36], form main contours for economic goal-setting in the course of the T.i.r. as shown in Fig. 2. Conditionally, such an economy can be called sustainable economy, since it ensures the achievement of sustainable development goals. It can also be called 'green', because it is based on the use of renewable ('green') natural resources and 'green' (environmentally friendly) technologies.

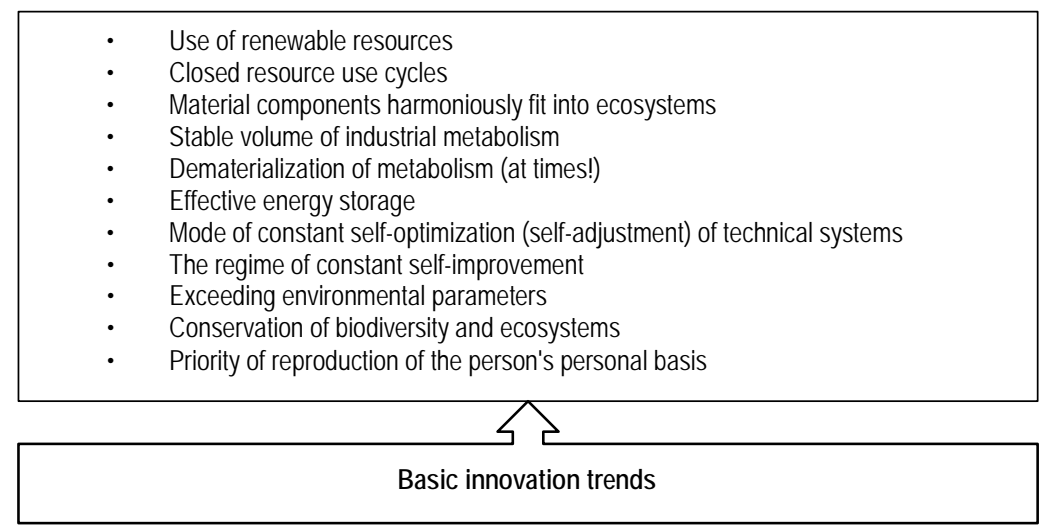

\section{Figure 2 - Key directions for socio-economic systems' transformations in the course of the T.i.r. (elaborated by the authors)}

In order to objectively analyze the essential content of the T.i.r., it is necessary to understand its essence, its underlying principles and how it differs from the previous industrial revolution.

The second industrial revolution reached its culmination, with the introduction of production lines for the mass production of standard consumer goods. Electricity became a single energy basis, driving diverse machinery and equipment. The high level of informatization of the production basis made it possible to greatly facilitate the processes of manufacturing products and managing complex technological systems. At the same time, an impetus was given to the development of science, the tremendous increase of the educational level of population and the formation of automated bases for information processing. It was the basis for the launch of the T.i.r. During the S.i.r. science turned into a productive force, that naturally determined the design and technological cycles of production systems, production processes remain the leading ones in terms of labor costs and expenditures. In the T.i.r. science, including design becomes the dominant link in the overall product development cycle. 
The Third industrial revolution, as we have already said, is aimed at solving the mentioned problem of the global ecological crisis. A necessary condition is a radical dematerialization of industrial metabolism, which finally must be accompanied by a significant decrease (at times!) of energy intensity and material consumption of human life processes.

The T.i.r. marks a series of basic innovation transitions from the fundamental features that distinguish the economy of the epoch of the S.i.r., to the characteristics of sustainable economy born in the course of the T.i.r. The main transitions can be expressed as follows:

- $\quad$ from primary use of non-renewable resources to primary use of renewable resources;

- $\quad$ from broken to closed cycles of nature management;

- $\quad$ from subtractive to additive technologies (in the first case, the process of manufacturing products occurs by cutting unnecessary, in the second - by adding necessary method, this is how 3D printers work);

- $\quad$ from multiple forms to a single digital form of fixing and transferring information;

- $\quad$ from isolated to network production systems;

- $\quad$ from vertical (complex-intermediary) to horizontal (direct) production and consumer structures;

- $\quad$ from capitalist or command to solidary forms of economic relations.

These transformations can be realized only when necessary prerequisites are created.

3. Objective factors for the T.i.r. to start. In addition to the prerequisites for the objective necessity of realizing a certain revolution, some events usually occur, that serve as a definite stimulating motive (a kind of a trigger) that launches the very revolution mechanism. The experts $[12 ; 14 ; 25]$ agree that the T.i.r. started in Europe at the end of 2000. Time and place, obviously, are not accidental.

The period of the EU's adoption of a set of measures to implement the T.i.r. coincided in time with 2007energy crisis, when oil price on world markets jumped on average from several tens to $\$ 120$ per barrel. World leading economies have reacted to this by a sharp price increase for manufactured goods and its general slowdown. When, in July 2008 , the price for a barrel of oil reached $\$ 147$, and the prices for manufactured goods increased drastically, doubling and tripling the price of certain groups of goods due to a sharp decline in the purchasing capacity of the population, the leading world economies practically stopped altogether. Two months after that, a severe financial crisis broke out.

In June 2007 a Directive plan known as 'Three 20s (20-20-20') was adopted in the EU. It pushed the EU countries by 2020 achieve the following: energy systems efficiency increase by $20 \%$, carbon dioxide emissions reduction by $20 \%$, renewable energy sources share increase in the energy balance of the European Union countries by $20 \%$ on average [14].

The European Parliament has obliged all the EU countries to bring the level of renewable energy sources (RES) use to $20 \%$ in the total generation of electricity (today it is already approaching the target) by 2020 . By 2040 the share of renewable energy sources is supposed to be increased to $40 \%$. In particular, in March 2017, the share of renewable energy in some EU countries was already more than $40 \%$.

According to the European Commission decision, since 2019 all public buildings in Europe must satisfy nearly Zero-Energy building principle - buildings with zero energy consumption and since 2021 - all new buildings must comply with such requirements. At the same time many buildings are transferred to closed schemes of water use. All houses are converted into mini-power plants for 'collecting' solar, wind, thermal (underground) and biogas energy. The house itself turns into an 'intelligent' automated system that manages engineering devices in an optimal mode [14]. In Germany, solar power plants installed on the roofs of skyscrapers have already allowed covering up to $50 \%$ of their own energy requirements [26].

It is planned to create a unified information and energy system (EnerNet) that will ensure the collection/purchase (from separate sources - mini-power stations), transmission, storage, conversion and use/sale of electricity in the most efficient mode. It is foreseen to exchange energy flows between certain regions (in particular, in the daytime, the southern European countries will supply the northern countries with solar, wind and biogas energy, and at night - northern countries will supply the energy generated by 
Л.Г. Мельник, І.Б.Дегтярьова, Д.В.Горобченко, О.М. Маценко. Інновації в ході сучасних трансформаційних процесів економіки підприємства, регіону, країни: досвід ЕС

hydroelectric power stations) [21].

In March 2011, there was, however, another event that forced the EU countries to intensify work on the implementation of the T.i.r. It was the largest in modern history radiation catastrophe (maximum $7^{\text {th }}$ level according to the International scale of nuclear explosions) at Fukushima-1 nuclear power plant (Japan). It forced the revision of the EU's strategic development plans.

The European Commission released its Energy Security Strategy in May 2014. The Strategy aims to ensure a sustainable energy supply for European citizens [33]. To ensure secure, sustainable, competitive and affordable energy for European consumers the European Commission presented an ambitious Energy Union Strategy. It was launched on 25 February 2015 [49]. On 30 November 2016, the Commission published a proposal for a revised Renewable Energy Directive to make the EU a global leader in renewable energy and ensure that the target of at least $27 \%$ renewables in the final energy consumption in the EU by 2030 is met [31].

In many EU countries, the share of electricity generated by nuclear power plants averaged between 30 and 40\% (Bulgaria, Hungary, Germany, Italy, Slovenia, Finland, and Sweden). In Slovakia and France more than half of the national electricity was produced by nuclear power plants ( $54 \%$ and $78 \%$, respectively) [3; 10]. The shock of the Japanese catastrophe was so strong that it forced us to seek a replacement for atom energy. In a relatively poor for fossil energy resources Europe, the problem could be solved only through the intensification of the use of renewable energy sources. Europe reacted by launching the processes in the whole chain of an integral systemic phenomenon called the 'Third Industrial Revolution'.

4. Sufficiency prerequisites and key innovations for the T.i.r. implementation. Any system is formed as the interaction of three principles (basic groups of factors): material, information, and synergetic. Conditionally (symbolically) their functions can be expressed in the following way: material - drive (work); information - direct (form information development algorithm); synergetic - combine (ensure coordinated behavior of individual subsystems). (See details in: [8]).

Fig. 3 shows the necessary basic prerequisites for the implementation of the T.i.r.

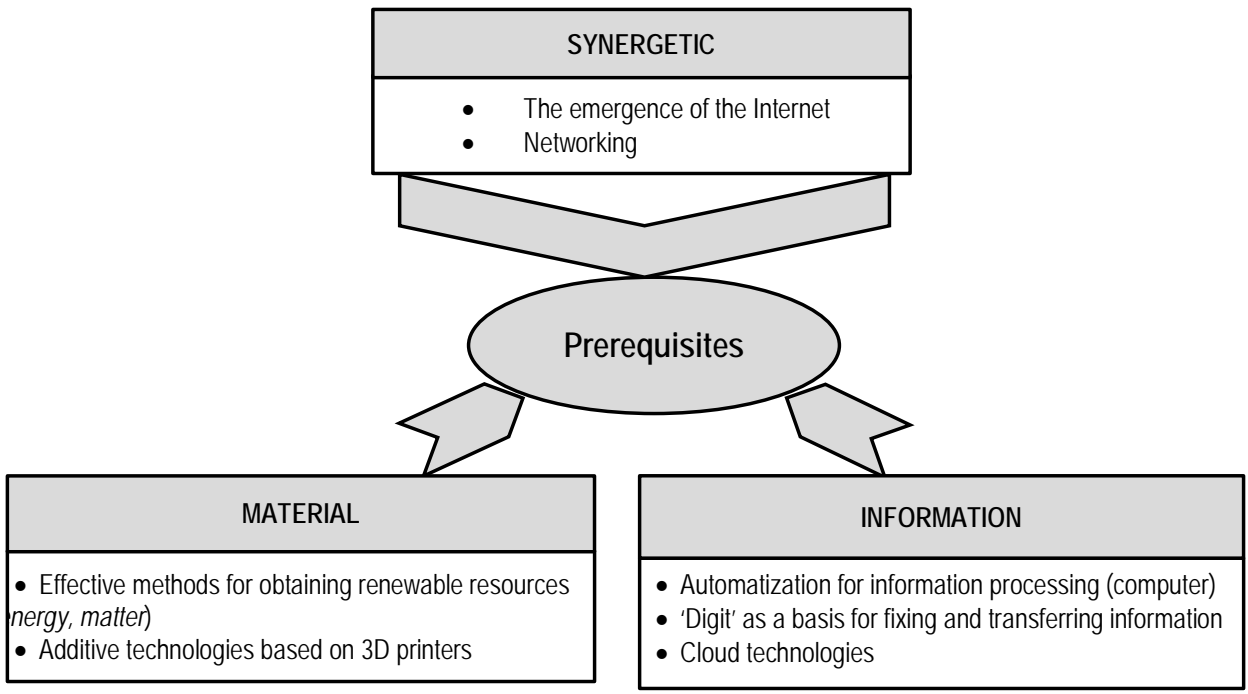

Figure 3 - Basic prerequisites (light box) and key innovations (grey box) for the launch of the Third Industrial Revolution (elaborated by the authors) 
They assume: first, the availability of effective (i.e., quite cheap for a unit of work performed) technical means (in particular, installations of alternative energy and 3D printers); secondly, the provision of a single ('digital') basis for fixing and transmitting information (for the implementation of communication between people, a man with a machine and a machine with a machine), as well as the formation of a global memory system and a unique 'planetary brain ocean' based on 'cloud' technologies; thirdly, the formation of a unified communication platform on the basis of the Internet and network systems.

A detailed analysis gives the understanding that each of the above mentioned groups of prerequisites determines two groups of prerequisites: technical and economic. The first one assumes the emergence of technical capabilities to solve a particular problem (for example, the creation of an appropriate tool). The second one refers to ensuring its cheapness, sufficient for mass introduction at the level of enterprises, regions and national economies.

Conventionality, we can say that the technical groups of prerequisites appeared during the S.i.r. Basic technical solutions for the creation of solar panels, wind generators, 3D printers and computers appeared that time. However, perfection, efficiency, manufacturability that led to a sharp price reduction was achieved with the launch of the T.i.r. However, it can be said in another way: the achievement of sufficient cheapness was the trigger that gave the start to the T.i.r.

The main innovation breakthrough of the T.i.r. provided cheapness and efficiency in: a) obtaining renewable energy; b) energy accumulation; c) production and operation of 3D printers; d) information fixation, processing and transmission. This is confirmed by many scientific publications.

5. Energy innovation. Since 1970, the cost of solar energy production has been reduced by 150 times (!). The alignment of prices for traditional and alternative energy forecasted for 2021was already achieved in 2015 [22; 47; 48].

A real struggle for a record price of solar energy began in 2016. At the beginning of the year SunEdiscn company offered a fantastically low price of $\$ 29.1$ per $1 \mathrm{MWh}$ of electricity at Chile auction. This is half the price of electricity received from coal power plants. In August, a new record was set in the UAE - \$ 24.2. Finally, Danish energy company Pure \& Better Energy set a new world record at the end of the year, selling $20 \mathrm{MWh}$ of solar energy at $\$ 18.1$ per $1 \mathrm{MWh}[9]$.

The European Union became the leader in 'green' energy development, as evidenced by the records of 'green' energy sector (Table 1).

Table 1 - Alternative energy records

\begin{tabular}{|l|l|c|}
\hline \multicolumn{1}{|c|}{ Period } & Type of energy produced, country (region), source & Energy share in total energy balance,\% \\
\hline 9.09 .2015 & Wind energy, Denmark [30] & $144 \%$ \\
\hline During 2015 & Wind energy, Denmark [30] & $42 \%$ (average, in 17\% of time reaches 100\%) \\
\hline 08.05 .2016 & Alternative energy (sun, wind). Germany [27; 29] & $87 \%$ \\
\hline $07.05-11.05 .2016$ (107 hours) & Renewable energy (sun, wind, biogas). Portugal [13] & $100 \%$ \\
\hline 02.10 .2017 & Wind energy. Scotland [4] & $206 \%$ \\
\hline Starting 01.01.2017 & $\begin{array}{l}\text { Wind energy for electric trains of the national } \\
\text { railways. The Netherlands [32] }\end{array}$ & $100 \%$ \\
\hline
\end{tabular}

It is generally stated that Ukraine is also in the trend of 'green' innovations, sustaining its energy and transport (Table 2).

The effects of energy and transport innovations are complemented by synergetic effects of technological innovation.

6. Technological innovations. The implementation of additive technologies is provided by the wide introduction of $3 \mathrm{D}$ printers. This is another major innovation. A well-known scientist Jeremy Rifkin stated: '3D printing marked the beginning of the Third Industrial Revolution' [45]. 
Л.Г. Мельник, І.Б.Дегтярьова, Д.В. Горобченко, О.М. Маценко. Інновації в ході сучасних трансформаційних процесів економіки підприємства, регіону, країни: досвід ЕС

Table 2 - Dynamics of green energy and green transport development in Ukraine

\begin{tabular}{|l|c|c|c|}
\hline \multicolumn{1}{|c|}{ Indexes, source } & \multicolumn{2}{c|}{ Years } \\
\cline { 2 - 4 } & 2015 & 2016 & $\begin{array}{c}2017 \text { (forecast } \\
\text { according to 9 months } \\
\text { of the year) }\end{array}$ \\
\hline Green energy capacity installed, MW (\% of total energy balance) [2; 5; 17] & $0,6(1,3)$ & $1(2)$ & $1,9(4,3)$ \\
\hline The number of RES installations in private households, units [18] & 244 & 1110 & 3030 \\
\hline RES capacity installed in private houses, MW [18] & 2,2 & 16,7 & 52,0 \\
\hline The number of registered electric vehicles in Ukraine, units. [16; 20] & 470 & 1602 & 3300 \\
\hline
\end{tabular}

In addition to the tremendous savings in raw material costs, technological costs for the preparation of production processes (labor, energy, materials) are minimized. A computer with a 3D printer manages the production processes and if necessary brings changes and diversifies products forms at minimal costs.

Company Context data, the world market of 3D printing will reach $\$ 17.8$ billion by 2020 , and the market for 3D printers in the period 2016-2020 will increase from 1.8 billion dollars to 6.4 billion dollars, with annual increase by $30-40 \%$. In 2016, the world produced about 2.5 thousand models of various 3D printers (Boing, Samsung, Siemens, Canon, and General Electric) [7].

A breakthrough in building sector using concrete 3D printing began in 2014. Shanghai company WinSun built ten 3D printed houses in 24 hours, and afterwards printed a five-storey house and a mansion [24].

Since 2013, 3D printers have been widely used in food industry [39]. As media reports leading shoe companies widely use 3D printing (about 10\%). A 3D printer has long been used on the international space station. In particular, missing tools are printed. If necessary, their digital images are transmitted from the Earth.

There were reports of a possible significant reduction in 3D printer cost. In particular, such a device can cost no more than a refrigerator - about 180 US dollars [6].

Today, technologies have become very cheap. For example, the production of sensors and RFID tags are as cheap as one dollar. This is a step towards mass production [23].

7. Economic transformation of enterprise, region, country. The forthcoming changes are aimed at transforming economic image of enterprise, region, and country. Today we can witness the following directions for innovation transformations:

- transferring the center of gravity (and consequently, costs) in the production process from product replication cycle (in other words, the production of goods) to design cycle forming the main value of the future product [1;39];

- significant dematerialization of production means and manufacturing process; the means of production are computerized: (algorithms, programs, databases); additive technologies sharply reduced the demand for raw materials, and due to its unification most of the logistics problems disappear [19];

- transition from large-scale industrial enterprises to networks of small or individual producers [42];

- transition to horizontal production and consumption structures, to solidary forms of economic relations $[15 ; 44]$;

- virtualization of enterprises, due to the creation of production networks, enterprises that are in different spatial conditions, often in different parts of the globe, can integrate their activities into single production cycles [38];

- intellectualization of production on the basis of 'cloud' technologies; in modern conditions, the creation of smart control systems, which not only take the optimization function of production processes in space and time, but also serve as an integrating principle, which units the activities of many (often hundreds, thousands or, as in the case of EnerNet energy system, millions) of economic agents is the reality [35];

- management networks of various levels are created: smart plant, smart house, smart city, smart 
highway, smart country; all of them are formed and function on the basis of a permanent connection to the Internet; the implementation of the Fourth Industrial Revolution and the 'Internet of Things' promise significant perspectives [37];

- creation of flexible plants; several US businesses began selling flexible plants (with software) that can operate in 24 hours [41];

- fables production (founder - Massachusetts Institute of Technology); using existing equipment the plant is able to self-adjust and self-expand the existing functional units $21 ; 35]$.

Thus, the main type of products in business sector are not products and services, but start-ups to produce innovations. Moreover, the range of innovations produced by start-ups is extremely wide and affects all spheres of life.

It is possible to name even more precisely the kind of objects that are sold in the form of a start-up these are various innovative forms for increasing the effectiveness of human life support processes.

Conclusions and further research. One important detail is worth emphasizing. The mentioned innovative technologies, like any innovations in general, can be successfully implemented with the concentration of the whole society efforts. In the EU countries, the so-called technology platforms as instruments for such concentration are used, covering the projected type of innovation from definition to the general research program. This term means the unification of state, business, science and education representatives around a common vision of scientific and technological development trend as well as the formation of common approaches to the development and industrial production of appropriate technologies [34].

Only consolidated participation of various associations and individual social entities will allow solving financial, organizational, technical, information and social problems of introducing clusters of modern technological innovations.

The Third industrial revolution promises to solve a number of economic, environmental and social problems. Its main result should be a significant decrease in the resource intensity of production systems and the reduction of anthropogenic pressure on natural systems. A significant increase in the efficiency of life support systems also creates a reliable platform for improving human welfare.

At the same time, it should be mentioned that the Third industrial revolution brings a number of social and humanitarian challenges. First of all, we should understand the phase scale of future transformations. People can benefit only if a civilizational transition to mass reproduction of a person dominated by his personal (information) needs takes place. The productive use of released free time, as a result of the radical automation of production processes, should also be directed at this.

1. Агамирзян И. Третья промышленная революция: начало [Электронный ресурс] / И. Агамирзян. - Режим доступа: https://www.slon.ru.

2. Альтернативная энергетика Украины: солнце, ветер и вода [Электронный ресурс]. - Режим доступа: https://delo.ua/business/alternativnaja-energetika-ukrainy-solnce-veter-i-voda-fotorep-299439/ .

3. Бобылёв Б.И. Атомная энергетика Европы [Электронный ресурс] / Б.И. Бобылёв. - Режим доступа: http://www.russika.ru/sa.php?s=2.

4. Ветровые турбины обеспечили $200 \%$ энергопотребностей Шотландии [Электронный ресурс]. - Режим доступа : https://ecotechnica.com.ua/energy/veter/2731-vetrovye-turbiny-obespechili-200-energopotrebnostej-shotlandii.html.

5. Возобновляемая энергетика в Украине: шаг вперед, два шага назад [Электронный ресурс]. - Режим доступа : https://news.finance.ua/ru/news/-/412239/vozobnovlyaemaya-energetika-v-ukraine-shag-vpered-dva-shaga-nazad.

6. Загорская Д. Цельный 3D-принтер обещает стоить не больше холодильника [Электронный ресурс] / Д. Загорская. - Режим доступа: http://www.vesti.ru/doc. html?id=2485308.

7. Курышев Е. Рынок 3D-принтеров в мире и в России. Новинки в мире технологий [Электронный ресурс] / Е. Курышев. - Режим доступа : http://www.it-weekly.ru/it-news/tech/105306.html .

8. Мельник Л.Г. Теория развития систем : монография / Л.Г. Мельник. - СаарБрюкен, Германия : Palmarium Academic Publishing, 2016. $-528 \mathrm{c}$

9. Ниже некуда - новый рекорд цен на солнечную энергию поставлен в Дании [Электронный ресурс]. - Режим доступа: http://ecotechnica.com.ua/energy/solntse/1897-nizhe-nekuda-nowyj-rekord-tsen-na-solnechnuyu-energiyu-postavlen-v-danii.html. 
10. Одессер С. Атомная энергетика европейских стран / С. Одессер // Экономика и финансы, 2016. - С. 20-21.

11. Омесь Ю. Третья промышленная революция и перспективы Украины (для «Хвилі») [Электронный ресурс] / Ю. Омесь. Режим доступа http:/hvylya.net/analytics/economics/tretya-promyishlennaya-revolyutsiya-i-perspektivyi-ukrainyi.html.

12. Перелет Р.А. «Зелёная» экономика в ЕС : Политика и практика [Электронный ресурс] / Р.А. Перелет. - Режим доступа : www.wecoop-project.org.

13. Португалия европейский рекордсмен по использованию возобновляемых источников энергии [Электронный ресурс] - Режим доступа : http://ru.euronews.com/2016/05/20/portugal-keeps-lights-on-using-only-renewable-energy.

14. Рифкин Дж. Мастер-класс. Часть 1 [Электронный ресурс] / Дж. Рифкин. - Режим доступа https://www.youtube.com/watch?v=WDbSWeptKCA.

15. Рифкин Дж. Третья промышленная революция. Как горизонтальные взаимодействия меняют энергетику, экономику и мир в целом, пер. с англ. / Дж. Рифкин. - Москва : Альпина-Нонфункшнн, 2016. - 410 с.

16. Самые популярные электромобили в Украине за первое полугодие 2017. Новости мира электромобилей в Украине [Электронный ресурс]. - Режим доступа: http://zemobiles.com/news/samye-populyarnye-elektromobili-v-ukraine-za-pervoepolugodie-20171.

17. Скрипин В. За первое полугодие в Украине построили 79 объектов возобновляемой энергетики суммарной мощностью 182,7 МВт, до конца года реализует ещё 70 проектов общей мощностью более 430 МВт [Электронный ресурс] / В. Скрипин. - Режим доступа : https://itc.ua/news/za-pervoe-polugodie-v-ukraine-postroili-79-obektov-vozobnovlyaemoy-energetiki-summarnoy-moshhnostyu182-7-mvt-do-kontsa-goda-realizuyut-eshhe-70-proektov-obshhey-moshhnostyu-bolee-430-mvt/.

18. Скрипин В. С начала года более 1200 украинских домохозяйств перешли на солнечную энергию. Абсолютным лидером выступает Киев и Киевская область [Электронный ресурс] / В. Скрипин. - Режим доступа : https://itc.ua/news/s-nachala-goda-bolee1200-ukrainskih-domohozyaystv-pereshli-na-solnechnuyu-energiyu-absolyutnyim-liderom-vyistupaet-kiev-i-kievskaya-oblast.

19. Сотник И. Н. Управление инновационным ресурсосбережением на микроуровне в условиях транссрормационных изменений экономики / И. Н. Сотник, И. В. Шевцов // Механізм регулювання економіки. - 2013. - № 1. - С. 47-53.

20. Статистика электромобилей в Украине от МВД. Electro Club, 05.05 .2017 [Электронный ресурс] - Режим доступа : http://www.electrocars.club/2017/05/05/статистика-электромобилей-в-украине/

21. Третья промышленная революция. Часть 2: «Заводы и рабочие места: назад к производству». The Economist/ пер с англ. И. Селиванов (апрель 2012). [Электронный ресурс] - Режим доступа : http://www.sputnikipogrom.com.

22. Фесенко Н. В Чилі зафіксована рекордно низька ціна на сонячну енергію - вдвічі нижча за вугільну [Електроний pecypc] / H. Фесенко. - Режим доступу: http://ecotown.com.ua/news/V-CHyli-zafiksovana-rekordno-nyzka-tsina-na-sonyachnuenerhiyu-vdvichi-nyzhcha-za-vuhilnul.

23. Четвёртая революция: Интернет вещей [Электронный ресурс]. - Режим доступа: http://www.ncca.ru/file?Files\&141.

24. Шанхайская компания WinSun напечатала пятиэтажный дом и особняк [Электронный ресурс]. - Режим доступа : http://3dtoday.ru/blogs/news3dtoday/shanghai-company-winsun-has-printed-a-fivestorey-house-and-mansion/

25. Щедровицкий П.Г. Третья промышленная революция. Выступление на XIX межрегиональной тьюторской конференции [Электронный ресурс] / П. Г. Щедровицкий. - Режим доступа : https://www.youtube.com/ watch?v=4a4qwUPJTik

26. Яковлєва Н. У Німеччині багатоповерхівки покриють до 50\% власних електропотреб завдяки встановленим на дахах сонячним станціям [Електроний ресурс] / Н. Яковлєва. - Режим доступа : http://ecotown.com.ua/news/U-Nimechchynibahatopoverkhivky-pokryyut-do-50-vlasnykh-elektropotreb-zavdyaky-vstanovlenym-na-dakhul.

27. Bolton D. People in Germany are now being paid to consume electricity: The price of power in Germany briefly dropped to -€130 per MWh on 8 May [Electronic resource] / D. Bolton. - Access mode : http://www.independent.co.uk/environment/renewableenergy-germany-negative-prices-electricity-wind-solar-a7024716.html.

28. Bostron N. Superintelligence: Paths, Dangers, Strategies / N. Bostron. - Oxford, UK : Oxford University Press, 2016 - 390 p.

29. Coren M.J. Germany had so much renewable energy on Sunday that it had to pay people to use electricity. [Electronic resource]. - Access mode : http://qz.com/680661/germany-had-so-much-renewable-energy-on-sunday-that-it-had-to-pay-people-touse-electricityl.

30. Denmark Just Produced $140 \%$ of its Electricity Needs with Renewable Wind Power. [Electronic resource]. - Access mode : http://www.ewao.com/a/1-denmark-just-produced-140-of-its-electricity-needs-with-renewable-wind-power/.

31. Directive of the European Parliament and of the Council [Electronic resource]. - Access mode: http://eurlex.europa.eu/legal-content/EN/TXT/?uri=CELEX:52016PC0767R\%2801\%29.

32. Dutch electric trains become $100 \%$ powered by wind energy. [Electronic resource]. - Access mode: https://www.theguardian.com/world/2017/jan/10/dutch-trains-100-percent-wind-powered-ns .

33. Energy Security Strategy [Electronic resource]. - Access mode: https://ec.europa.eu/energy/en/topics/energystrategy/energy-security-strategy.

34. European Technology Platforms (ETP). Innovation Union. European Commision [Electronic resource]. - Access mode : http://ec.europa.eu/research/innovation-union/index en.cfm?pg=etp.

35. Gershenfeld N. Macrofabrication with digital Material: Robotic Assembly / N. Gershenfeld, M. Carney, B. Jenett, S. Calisch, S. Wilson. - Architectural Design.85.2015. - P. 122-127.

36. Global Footprint Network. Ecological Wealth of Nations [Electronic resource]. - Access mode : www.footprintnetwork.org.

37. Greengard S. The Internet of Thing / S. Greengard. - Cambridge, USA : MIT Press, 2015. - $232 \mathrm{p}$ 
38. Kellmereit D. The Silent Intelligence: The Internet of Things / D. Kellmereit. - San Francisco : DND Ventures LLC, 2013. - 166 p.

39. Kolodny L. Bee Hex cooks up $\$ 1$ million for 3D food printers that make pizzas [Electronic resource] / L. Kolodny. - Access mode : https://techcrunch.com/2017/02/28/beehex-cooks-up-1-million-for-3d-food-printers-that-make-pizzas/.

40. Kurzweil R. The Singularity is Near: When Hamans Transcend Biology / R. Kurzweil. - London : Penguin Books, 2006. - 672 p

41. Lavars N. Factory-in-a-Day Project Aims to Deploy Work-ready Robots Within 24 Hours [Electronic resource] / N. Lavars. Robotics Dec. 9, 2013. - Access mode : newatlas.com.

42. McEwen A. Designing the Internet of Things / A. McEwen, H. Cassimally. - New York : John Wiley \& Sons, Ltd, 2014. - 338 p

43. Mindell D.A. Between Human and Machine: Feedback, Control, and Computing before Cybernetics / D.A. Mindell. - JHU Press, 2002, 29 August. $-439 p$.

44. Rifkin J. The Third Industrial Revolution: How Lateral Power is Transforming Energy, The Economy, and The World / J. Rifkin. - New York : St. Martin's Griffin Publisher, 2013. - 304 p.

45. Rifkin J. Zero Marginal Cost Society: The Internet of Things, the Collaborative Commons, and the Eclipse of Capitalism / J. Rifkin. - New York : St. Martin's Griffin Publisher, 2015. - 448 p.

46. Schwab K. The Fourth Industrial Revolution / K. Schwab. - The Financial Times Limited, 2016. - 198 p.

47. Shahan Z. 10 Solar Energy Facts \& Charts You (\& Everyone) Should Know [Electronic resource] / Z. Shahan. - Access mode : https://cleantechnica.com/2016/08/17/10-solar-energy-facts-charts-everyone-know/.

48. Shanahan M. The Technological Singularity / M. Shanahan. - Cambridge, USA : MIT Press, 2015 - $272 \mathrm{p}$.

49. The Energy Union: A New Start? [Electronic resource]. - Access mode: http://webershandwick.be/wpcontent/uploads/2015/03/WS-Energy-talks-FINAL.pdf.

1. Agamirzyan I. Tret'ya promyshlennaya revolyuciya: nachalo [The Third Industrial Revolution: the Beginning] (n.d.). slon.ru. Retrieved from https://www.slon.ru [in Russian].

2. Alternativnaya energetika Ukrainy: solntse. veter i voda (2015). Energetika: delovoy novostnoy sayt [site Energy: business news site]. delo.ua. Retrieved from: https://delo.ua/business/alternativnaja-energetika-ukrainy-solnce-veter-i-voda-fotorep-299439/ [in Russian].

3. Bobylev, B.I. (2016). Atomnaya energetika Evropy [Atom energy of Europe]. russika.ru. Retrieved from http://www.russika.ru/sa.php?s=2 [in Russian].

4. EkoTekhnika (2017). Vetrovye turbiny obespechili 200\% energopotrebnostey Shotlandii [Wind Turbines Provided $200 \%$ of Scotland's Energy Needs. Site Ecotechnika]. ecotechnica.com.ua. Retrieved from https://ecotechnica.com.ua/energy/veter/2731vetrovye-turbiny-obespechili-200-energopotrebnostej-shotlandii.html [in Russian].

5. Vozobnovlyaemaya ehnergetika v Ukraine: shag vpered, dva shaga nazadv [Renewable energy in Ukraine: a step forward, two steps back] (2017). news.finance.ua. Retrieved from https://news.finance.ua/ru/news/-/412239/vozobnovlyaemaya-energetikav-ukraine-shag-vpered-dva-shaga-nazad [in Russian].

6. Zagorskaya, D. (2015). Cel'nyj 3D-printer obeshchaet stoit' ne bol'she holodil'nika [A 3D printer promises to cost no more than a refrigerator]. vesti.ru. Retrieved from http://www.vesti.ru/doc.html?id=2485308 [in Russian].

7. Kuryshev, E. (2016). Rynok 3D-printerov v mire i v Rossii. Novinki v mire tekhnologiy [The market of 3D printers in the world and in Russia. Novelties in the world of technology]. it-weekly.ru. Retrieved from http://www.it-weekly.ru/it-news/tech/105306.html [in Russian].

8. Melnik, L.G. (2016). Teoriya razvitiya sistem [The theory of system development]. Saarbrücken: Palmarium Academic Publishing [in Russian].

9. Nizhe nekuda - novyy rekord tsen na solnechnuyu energiyu postavlen v Danii [The cheapest price - a new prices record for solar energy in Denmark] (2016). ecotechnica.com.ua. Retrieved from http://ecotechnica.com.ua/energy/solntse/1897-nizhenekuda-novyj-rekord-tsen-na-solnechnuyu-energiyu-postavlen-v-danii.html [in Russian].

10. Odesser, S. (2016). Atomnaya energetika evropeyskikh stran [Nuclear power of European countries]. Ekonomika i finansy - Economics and Finances, 20-21 [in Russian].

11. Omes, Yu. (n.d.). Tretya promyshlennaya revolyutsiya i perspektivy Ukrainy (dlia «Khvyli») [The Third Industrial Revolution and the Prospects of Ukraine]. hvylya.net. Retrieved from http://hvylya.net/analytics/economics/tretya-promyishlennayarevolyutsiya-i-perspektivyi-ukrainyi.html [in Russian].

12. Perelet, R.A. (2015). Zelenaya» ekonomika v ES : Politika i praktika [Green Economy in the EU: Policy and Practice] wecoop-project.org. Retrieved from www.wecoop-project.org [in Russian].

13. Portugaliya evropeyskiy rekordsmen po ispolzovaniyu vozobnovlyayemykh istochnikov energii [Portugal is the European record holder for the use of renewable energy sources] (2016). ru.euronews.com. http://ru.euronews.com/2016/05/20/portugalkeeps-lights-on-using-only-renewable-energy [in Russian]

14. Rifkin, D. (2014). Master-klass. Chast' 1. [Master class. Part 1]. youtube.com. Retrieved from https://www.youtube.com/watch?v=WDbSWeptKCA [in Russian].

15. Rifkin, D. (2016) Tretya promyishlennaya revolyutsiya. Kak gorizontalnyie vzaimodeystviya menyayut energetiku, ekonomiku i mir v tselom [The Third Industrial Revolution. How horizontal interactions change energy, economy and the world as a whole]. Moskva: Alpina Pablisher [in Russian].

16. Samye populyarnye elektromobili v Ukraine za pervoye polugodiye 2017. Novosti mira elektromobiley v Ukraine [The most 
popular electric vehicles in Ukraine for the first half of 2017. News of the world of electric cars in Ukraine] (2017). zemobiles.com. Retrieved from http://zemobiles.com/news/samye-populyarnye-elektromobili-v-ukraine-za-pervoe-polugodie-2017 [in Russian].

17. Skripin, V. (2017) Za pervoe polugodie v Ukraine postroili 79 obyektov vozobnovlyayemoy energetiki summarnoy moshchnostyu 182.7 MVt. do kontsa goda realizuyet eshche 70 proyektov obshchey moshchnostyu boleye $430 \mathrm{MVt}$ [For the first half-year in Ukraine, 79 renewable energy facilities with a total capacity of $182.7 \mathrm{MW}$ have been built, and by the end of the year 70 projects with a total capacity of more than $430 \mathrm{MW}$ has been implemented]. itc.ua. Retrieved from https:/litc.ua/news/za-pervoepolugodie-v-ukraine-postroili-79-obektov-vozobnovlyaemoy-energetiki-summarnoy-moshhnostyu-182-7-mvt-do-kontsa-godarealizuyut-eshhe-70-proektov-obshhey-moshhnostyu-bolee-430-mvt/ [in Russian].

18. Skripin, V. (2017). S nachala goda bolee 1200 ukrainskikh domokhozyaystv pereshli na solnechnuyu energiyu. Absolyutnym liderom vystupayet Kiyevi Kiyevskaya oblast [Since the beginning of the year more than 1200 Ukrainian households switched to solar energy. The absolute leader is Kiev and Kiev region]. itc.ua. Retrieved from https://itc.ua/news/s-nachala-goda-bolee-1200-ukrainskihdomohozyaystv-pereshli-na-solnechnuyu-energiyu-absolyutnyim-liderom-yyistupaet-kiev-i-kievskaya-oblast/ [in Russian].

19. Sotnik, I.N. \& Shevtsov, I.V. (2013). Upravlenie innovatsionnyim resursosberezheniem na mikrourovne $v$ usloviyah transformatsionnyih izmeneniy ekonomiki. [Management of innovative resource-saving at the micro level in conditions of transformational changes in the economy]. Mekhanizm rehuliuvannia ekonomiky - Mechanism of Economic Regulation, 1, 47-53 [in Russian].

20. Statistika elektromobiley v Ukraine ot MVD (2017) [Statistics of electromobiles in Ukraine from the Ministry of Internal Affairs] electrocars.club. Retrieved from http://www.electrocars.club/2017/05/05/статистика-электромобилей-в-украине [in Russian].

21. Tretya promyishlennaya revolyutsiya. (Chast 2) «Zavodyi i rabochie mesta: nazad k proizvodstvu» [The Third Industrial Revolution. Part 2: "Factories and jobs: back to production"] (2012). sputnikipogrom.com. Retrieved from http://www.sputnikipogrom.com [in Russian].

22. Fesenko, N. (2016). V Chyli zafiksovana rekordno nyzka tsina na soniachnu enerhiiu - vdvichi nyzhcha za vuhilnu [Chile has recorded a low price record for solar energy - twice lower than coall. ecotown.com.ua. Retrieved from http://ecotown.com.ua/news $N$-CHylizafiksovana-rekordno-nyzka-tsina-na-sonyachnu-enerhiyu-vdvichi-nyzhcha-za-vuhilnul [in Ukrainian].

23. Chetvyortaya revolyutsiya: Internet veschey [The Fourth Revolution: The Internet of Things]. (n.d.). ncca.ru. Retrieved from http://www.ncca.ru/file?Files\&141 [in Russian].

24. Shankhayskaya kompaniya WinSun napechatala pyatietazhnyy dom i osobnyak [Shanghai company WinSun has printed a five-story house and a mansion] (2017). 3dtoday.ru. Retrieved from http://3dtoday.ru/blogs/news3dtoday/shanghai-companywinsun-has-printed-a-fivestorey-house-and-mansion/ [in Russian].

25. Schedrovitskiy, P.G. (2014). Tretya promyishlennaya revolyutsiya. Vyistuplenie na XIX mezhregionalnoy tyutorskoy konferentsii [The Third Industrial Revolution. Speech at the XIX interregional tutorial conference]. youtube.com. Retrieved from https://www.youtube.com/ watch?v=4a4qwUPJTik [in Russian].

26. Yakovlieva, N.U. (2017). U Nimechchyni bahatopoverkhivky pokryiut do 50\% vlasnykh elektropotreb zavdiaky vstanovlenym na dakhakh soniachnym stantsiiam [In Germany, up to 50\% of its own electricity needs due to the installation of solar panels on roofs skyscrapers will be covered]. ecotown.com.ua. Retrieved from http:/lecotown.com.ua/news/U-Nimechchynibahatopoverkhivky-pokryyut-do-50-vlasnykh-elektropotreb-zavdyaky-vstanovlenym-na-dakhu/ [in Ukrainian].

27. Bolton, D. (2016). People in Germany are now being paid to consume electricity: The price of power in Germany briefly dropped to $€ 130$ per MWh on 8 May. independent.co.uk. Retrieved from http://www.independent.co.uk/environment/renewableenergy-germany-negative-prices-electricity-wind-solar-a7024716.html

28. Bostron, N. (2016). Superintelligence: Paths, Dangers, Strategies. Oxford: Oxford University Press.

29. Coren, M.J. (2016). Germany had so much renewable energy on Sunday that it had to pay people to use electricity. qz.com. Retrieved from http://qz.com/680661/germany-had-so-much-renewable-energy-on-sunday-that-it-had-to-pay-people-to-use-electricity/.

30. Denmark Just Produced 140\% of its Electricity Needs with Renewable Wind Power. Ewao (2015). ewao.com. Retrieved from http://www.ewao.com/a/1-denmark-just-produced-140-of-its-electricity-needs-with-renewable-wind-power/.

31. Directive of the European Parliament and of the Council (2017). eur-lex.europa.eu. Retrieved from http://eurlex.europa.eu/legal-content/EN/TXT/?uri=CELEX:52016PC0767R\%2801\%29.

32. Dutch electric trains become $100 \%$ powered by wind energy (2017). theguardian.com. Retrieved from https://www.theguardian.com/world/2017/jan/10/dutch-trains-100-percent-wind-powered-ns.

33. Energy Security Strategy (2016). ес.europa.eu. Retrieved from https://ec.europa.eu/energy/en/topics/energystrategy/energy-security-strategy.

34. European Technology Platforms (ETP). Innovation Union. European Commission. (n.d.). ec.europa.eu. Retrieved from http://ec.europa.eu/research/innovation-union/index_en.cfm?pg=etp.

35. Gershenfeld, N., Carney, M., Jenett, B., Calisch, S., \& Wilson S. (2015). Macrofabrication with digital Material: Robotic Assembly. Architectural Design, 85, 122-127.

36. Global Footprint Network. Ecological Wealth of Nations (n.d.). footprintnetwork.org. Retrieved from www.footprintnetwork.org

37. Greengard, S. (2015). The Internet of Thing. Cambridge: MIT Press.

38. Kellmereit, D. (2013). The Silent Intelligence: The Internet of Things. San Francisco: DND Ventures LLC.

39. Kolodny, L. (2017). Bee Hex cooks up \$1 million for 3D food printers that make pizzas. techcrunch.com. Retrieved from https://techcrunch.com/2017/02/28/beehex-cooks-up-1-million-for-3d-food-printrs-that-make-pizzas/. 
40. Kurzweil, R. (2006). The Singularity is Near: When Hamans Transcend Biology. London: Penguin Books.

41. Lavars, N. (2013). Factory-in-a-Day Project Aims to Deploy Work-ready Robots Within 24 Hours. Robotics. newatlas.com. Retrieved from https://newatlas.com.

42. McEwen, A., \& Cassimally, H. (2014). Designing the Internet of Things. New York: John Wiley \& Sons.

43. Mindell, D. A. (2002). Between Human and Machine: Feedback, Control, and Com $\neg$ puting be $\neg$ fore Cybernetics. JHU Press.

44. Rifkin, J. (2013). The Third Industrial Revolution: How Lateral Power is Transforming Energy, The Economy, and The World. New York: St. Martin's Griffin Publisher.

45. Rifkin, J. (2015). Zero Marginal Cost Society: The Internet of Things, the Collaborative Commons, and the Eclipse of Capitalism. New York: St. Martin's Griffin Publisher.

46. Schwab, K. (2016). The Fourth Industrial Revolution. The Financial Times Limited.

47. Shahan, Z. (2016). 10 Solar Energy Facts \& Charts You (\& Everyone) Should Know. cleantechnica.com. Retrieved from https://cleantechnica.com/2016/08/17/10-solar-energy-facts-charts-everyone-know/.

48. Shanahan, M. (2015). The Technological Singularity. Cambridge: MIT Press.

49. The Energy Union: A New Start? Weber Shandwick energy talks (2015). webershandwick.be. Retrieved from http://webershandwick.be/wp-content/uploads/2015/03/WS-Energy-talks-FINAL.pdf.

Л.Г. Мельник, д-р. екон. наук, професор, завідувач кафедри економіки та бізнес-адміністрування, Сумський державний університет (м. Суми, Україна);

І.Б. Дегтярьова, канд. екон. наук, доцент, доцент кафедри економіки та бізнес-адміністрування, Сумський державний університет (м. Суми, Україна);

Д.В. Горобченко, канд. екон. наук, старший викладач кафедри економіки та бізнес-адміністрування, Сумський державний університет (м. Суми, Україна);

О.М. Маценко, канд. екон. наук, доцент, доцент кафедри економіки та бізнес-адміністрування, Сумський державний університет (м. Суми, Україна)

Інновації в ході сучасних трансформаційних процесів економіки підприємства, регіону, країни: досвід ЕС

У статті розкривається зміст «зеленої» (сестейнової) економіки і роль Третьої промислової революції (Т.п.р.) і генерованих нею інновацій в її формуванні. Аналізуються закономірності виникнення T.п.р. і необхідні передумови для реалізації. Розглядаються основні види інноваційних переходів при формуванні економіки нового типу. Досліджуються напрямки трансформації економічних систем різних рівнів. Аналізується досвід ЄС.

Ключові слова: інновації, Третя промислова революція, відновлювані ресурси, «зелена» (сестейнова) економіка, адитивні технології, мережі.

Л.Г. Мельник, д-р. экон. наук, профессор, заведующий кафедрой экономики и бизнес-администрирования, Сумский государственный университет (г. Сумы, Украина);

И.Б. Дегтярева, канд. экон. наук, доцент, доцент кафедры экономики и бизнес-администрирования, Сумский государственный университет (г. Сумы, Украина);

Д.В. Горобченко, канд. экон. наук, старший преподаватель кафедры экономики и бизнес-администрирования, Сумский государственный университет (г. Сумы, Украина);

A.M. Маценко, канд. экон. наук, доцент, доцент кафедры экономики и бизнес-администрирования, Сумский государственный университет (г. Сумы, Украина)

Инновации в ходе современных трансформационных процессов в экономике предприятия, региона, страны: опыт EC

В статье раскрывается содержание «зеленой» (сестейновой) экономики и роль Третьей промьшленной революции (T.n.p.) и генерируемых ею инноваций в формировании. Анализируются закономерности возникновения T.n.p. и необходимые предпосылки для реализации. Рассматриваются основные виды инновационных переходов при формировании экономики нового типа. Исследуются направления трансформации экономических систем различных уровней. Анализируется опьт ЕC.

Ключевые слова: инновации, Третья промышленная революция, возобновляемые ресурсы, «зеленая» (сестейновая) экономика, аддитивные технологии, сети.

Отримано 11.03.2017 p. 